\title{
Optimization of Mycelial Culture Conditions and Fructification of Lentinus Species Using Rice Straw and Sawdust Based Substrates
}

\author{
Kalaw SP ${ }^{1,2}$, Dulay $\mathrm{RMR}^{1,2}$, Damaso $\mathbf{E J}^{1}$, Ramos $\mathrm{JC}^{\mathbf{1}}$, del Rosario MAG ${ }^{1}$, \\ Abon MD ${ }^{1}$, De Leon $\mathrm{AM}^{1,2}$, Undan $\mathrm{JR}^{1,2}$ and Reyes $\mathrm{RG}^{1,2}$
}

${ }^{1}$ Tuklas Lunas Development Center, Central Luzon State University, Science City of Munoz, Nueva Ecija, Philippines 3120

${ }^{2}$ Department of Biological Sciences, College of Science, Central Luzon State University, Science City of Munoz, Nueva Ecija, Philippines 3120

Kalaw SP, Dulay RMR, Damaso EJ, Ramos JC, del Rosario MAG, Abon MD, De Leon AM, Undan JR, Reyes RG 2021 - Optimization of Mycelial Culture Conditions and Fructification of Lentinus Species Using Rice Straw and Sawdust Based Substrates. Studies in Fungi 6(1), 519-530, Doi 10.5943/sif/6/1/42

\begin{abstract}
Lentinus (Basidiomycota, Polyporaceae) species are naturally-occurring mushrooms with nutritional and pharmacological importance. Unlike shiitake Lentinula edodes, a widely cultivated mushroom, Lentinus species are often ignored because they are underutilized and unpopular. However, like shiitake, Lentinus spp. could also be valuable resources of functional food and bioactive compounds. It is therefore of high interest to understand their cultural requirements leading to their efficient biomass production. Thus, this study established the optimal culture conditions for the maximum mycelial growth of seven wild strains under four Lentinus species. Their cultivation potentials were also determined using rice straw and sawdust $(7: 3 \mathrm{v} / \mathrm{v})$ substrate formulation. Mycelia of all Lentinus strains evaluated favorably grew on coconut water gulaman (local crude agar) and other culture media for specific strain with suitable $\mathrm{pH}$ ranging from 5.0 to 8.0. Aeration was not a major physical factor for all Lentinus strains except $L$. squarrosulus strain 1 , which favored sealed condition. Both lighted and dark conditions were found suitable for both strains of L. sajor-caju, L. strigosus strain 2 and L. swartzii whereas both strains of L. squarrosulus and L. strigosus strain 1 favorably grew in lighted condition. However, all Lentinus strains evaluated recorded the highest mycelial growth rates and thick mycelia at $30^{\circ} \mathrm{C}$. In terms of fruiting body production, all Lentinus strains demonstrated cultivation potential. The seven Lentinus strains completely colonized the substrate for 18.0-25.6 days and initiated primordia for 21.6-33.5 days. The highest yield (52.5 $\mathrm{g} \mathrm{bag}^{-1}$ ) and biological efficiency (10.5\%) was recorded in L. strigosus strain 1, whereas the lowest was noted in L. strigosus strain 2 with $21.1 \mathrm{~g} \mathrm{bag}^{-1}$ yield and $4.2 \%$ biological efficiency. L. sajor-caju strain 2 and $L$. squarrosulus strain 1 showed the widest cap diameter and longest stipe, respectively. The mycelial growth and fruiting body performance of Lentinus may vary depending on species and strains. Altogether, the seven new wild strains of Lentinus can be artificially cultivated by providing the nutritional and physical requirements.
\end{abstract}

Key words - fruit body - formation medicinal mushrooms - mycelia - nutritional requirements physical factors 


\section{Introduction}

Mushrooms are Ascomycetous or Basidiomycetous, epigeous or hypogeous, edible or poisonous macrofungi with distinctive fruiting bodies. They are rich sources of valuable nutrients, which are considered nutritious food. The dry matter of mushrooms contains 50\%-65\% carbohydrates, 19\%-35\% proteins, and 2\%-6\% fat (Dulay et al. 2014, Rathore et al. 2017). Mushrooms are also a good source of different dietary fiber with non-dietary carbohydrates, amino acids, vitamins, minerals and fatty acids (Rathore et al. 2017, Painuli et al. 2020, Bengu 2020). Apart from the nutritional values, mushrooms also produce various biologically-active compounds. Lentinula edodes, for instance, contain lenthionine, lentinan, other polysaccharides, amino acids, vitamins (B1, B2, C, D) and dietary fibers, which exhibit several biological activities including antimicrobial, cytotoxic, antitumor, anti-inflammatory, antioxidant, anti-aging, anti-hepatitis and immune-enhancing (Xu et al. 2014, Wang et al. 2015, Kupcova et al. 2018, Chung et al. 2019). Accordingly, mushroom is now being used as an ingredient to improve the nutritional and functional qualities of food products and dietary supplements.

The Philippine archipelago is a natural habitat of diverse macrofungal species. Several species listing and biodiversity studies have been conducted in the different areas of the country particularly in Luzon Island (De Leon et al. 2012, De Castro \& Dulay 2015, Tadiosa \& Arsenio 2014, Arenas et al. 2015, 2018, Dulay \& Maglasang 2017, Culala \& Dulay 2018, Dulay et al. 2020a). The most common macrofungal genera that have been recorded in the above-cited studies include Ganoderma, Lentinus, Schizophyllum, Volvariella, Collybia, Polyporus, Trametes, Pycnoporus, Auricularia, Pleurotus, Panaeolus, Termitomyces, Coprinus, Dictyophora, Oudemansiella, Chlorophyllum, Marasmius and Xylaria. Lentinus (Polyporaceae), also known as sawgill mushrooms, are wood-rotting basidiomycetous mushrooms that naturally grow in a wide temperature range, from the tropical to temperate regions. Species of this genus are relative to the widely cultivated and medicinal shiitake (Lentinula edodes) mushroom. Mushrooms such as $L$. tigrinus, L. sajor-caju, L. strigosus and L. swartzii contain carbohydrates, proteins, crude fibers, crude fat, vitamins, minerals and important bioactive metabolites such as alkaloids, flavonoids, phenols, coumarins, triterpenes, tannins, saponins, anthraquinones, athrones and steroids (Dulay et al. 2012, De Leon et al. 2017a, Dulay \& Pamiloza 2018, Austria et al. 2021). Moreover, Lentinus species exhibit antioxidant, antibacterial, antidiabetic, anti-HIV, anticancer, and other biological properties (Dulay et al. 2012, Dulay et al. 2017a, Xu et al. 2012, Udchumpisai \& Bangyeekhun 2019a, b).

Recently, a number of geographical wild species/strains of Lentinus have been documented and collected from different regions of Luzon Island including Isabela, Cagayan Valley, Ilocos Sur, Nueva Vizcaya, Nueva Ecija, Zambales, Tarlac, Quezon Province, and Camarines Sur. Mycelia from the wild Lentinus fruiting bodies have been successfully rescued and included in the list of our culture collections of Philippine wild mushrooms at the Center for Tropical Mushroom Research and Development, Central Luzon State University. Since Lentinus is one of the promising mushroom genus for their nutritional and pharmacological properties, it is necessary to understand their cultural requirements that would lead to the generation of the practical technology for mushroom biomass production for culinary and medicinal applications, thus, this study was conducted. The optimal cultural conditions for mycelial growth of seven strains under four Lentinus species, namely L. sajor-caju, L. squarrosulus, L. strigosus, and L. swartzii from the Philippines are reported herein.

\section{Materials \& Methods}

\section{Lentinus cultures}

The mycelial cultures of Lentinus species were acquired from the Center for Tropical Mushroom Research and Development, Central Luzon State University, Science City of Munoz, Nueva Ecija, Philippines. The identification of the mushroom species was previously confirmed using rDNA-ITS sequence analysis. To prepare mycelial inoculant, the mycelial blocks of each 
mushroom was inoculated on potato dextrose agar plate and incubated at $30^{\circ} \mathrm{C}$ to allow fungal growth. After seven days of incubation, mycelial discs were prepared using a flame-sterile cork borer and were used as inoculants in the growth evaluation.

\section{Evaluation of culture media and $\mathrm{pH}$}

A total of eight culture media were used in this study. Four indigenous culture media, namely coconut water gulaman (CWG), potato sucrose gulaman (PSG), corn grit decoction gulaman (CGDG), and rice bran decoction gulaman (RBDG), and four commercially-available dehydrated media, namely potato dextrose agar (PDA), malt extract agar (MEA), Sabouraud dextrose agar (SDA), and mycological agar (MA) were evaluated. Decoctions of $250 \mathrm{~g}$ potato cubes, $50 \mathrm{~g}$ rice bran, and $50 \mathrm{~g}$ corn grit in $1 \mathrm{~L}$ distilled water were separately prepared. Coconut water and the three decoctions were separately boiled and added with $10 \%$ gulaman (local crude agar) and 1\% sucrose for PSG only. Boiling was maintained until homogenized. Dehydrated media were prepared according to the instructions provided by the manufacturer. All media were dispensed into Erlenmeyer flask with cotton plugged, sterilized at $15 \mathrm{psi}, 121^{\circ} \mathrm{C}$ for $20 \mathrm{~min}$, pour-plated and solidified. Three replicates of each medium were prepared. Each plated culture media was aseptically inoculated with a $10 \mathrm{~mm}$-diameter mycelial disc and incubated at $30^{\circ} \mathrm{C}$. Mycelial growth diameter was measured and the mycelial growth rate was calculated for each strain. Mycelial thickness was also noted.

After determining the optimal medium for each mushroom, the optimum $\mathrm{pH}$ of the medium was determined. $\mathrm{pH}$ of the culture media was adjusted from 5.0 to 8.0 with 0.5 interval. Media were sterilized in the same conditions, pour-plated and solidified. These were inoculated with mycelial discs, incubated at $30^{\circ} \mathrm{C}$. The mycelial growth rate and thickness were also recorded.

\section{Evaluation of aeration, illumination and temperature}

The effects of the three physical environmental factors, namely aeration, illumination and temperature were also investigated in this study. Mycelial plate cultures of Lentinus species were prepared using the optimal medium with the optimum $\mathrm{pH}$ of each mushroom. These plate cultures were incubated in two aeration conditions (sealed and unsealed), two illumination conditions [artificial light $\left(322.92\right.$ lumens $\left./ \mathrm{m}^{2}\right)$ and dark], and temperature conditions $\left(9,23,30^{\circ} \mathrm{C}\right)$. Three replicate plates were done in each condition. Mycelial growth rate and mycelial thickness were determined.

\section{Grain spawn preparation}

Unmilled rice was used as the substrate for the spawn production of Lentinus species. The preparation, sterilization, inoculation and incubation of grain spawn described in the previous work of Dulay et al. (2017b) were adopted with minor modification. Once fully ramified with mycelia, grain spawn was used as inoculant in the production of mushrooms.

\section{Fruiting body production}

Rice straw and sawdust were the basal substrates used to determine the fruiting body production and bio-efficiency of the Lentinus species. The substrate with formulation of 7:3 v/v ratio of rice straw and sawdust was prepared, bagged $(500 \mathrm{~g})$ and compacted in $6 \times 12$ inches polypropylene bag with cotton plugs. Three substrate bags were prepared for each mushroom. Bags were sterilized at $15 \mathrm{psi}, 121^{\circ} \mathrm{C}$ for $1 \mathrm{~h}$. After cooling, $40 \mathrm{~g}$ of grain spawn was aseptically inoculated into each bag and subsequently incubated in the optimal culture conditions until full colonization. The period of incubation and primordial development were recorded. After incubation, bags were transferred into the growing house with $26-28^{\circ} \mathrm{C}$ and $80-90$ relative humidity, opened and watered to allow fruiting body emergence. Fruiting bodies were harvested and weighed. The biological efficiency was determined. 


\section{Statistical analysis}

Data were analyzed using Analysis of Variance and compared using Turkeys HSD and t-test at $5 \%$ level of significance.

\section{Results}

\section{Suitable culture media}

The effect of different culture media on the mycelial growth of seven strains of four Lentinus species was investigated (Table 1). Among eight culture media evaluated, CWG showed the highest mycelial growth rate in all strains of Lentinus and thick mycelia were observed. Aside from CWG, other culture media were also found suitable for the growth of specific strains. For instance, $L$. sajor-caju strain 1 favored MEA and SDA, L. squarrosulus strain 1 favored RBDG, and $L$. swartzii preferred PSG, CGDG and MEA. All culture media were found suitable for L. strigosus strain 2 and L. sajor-caju strain 2, except CGDG and MEA for the latter strain.

\section{Effect of pH}

The effects of varying $\mathrm{pH}$ levels on the mycelial growth of seven Lentinus strains are presented in Table 1. Apparently, culture media with $\mathrm{pH} 5-8$ were found suitable for the mycelial growth of all Lentinus strains. However, the seven Lentinus strains exceedingly favoured $\mathrm{pH} 5.0$ 5.5 for L. sajor-caju strain 1, pH 5.0-6.5 for L. sajor-caju strain 2, $\mathrm{pH}$ 5.0-6.0 for L. squarrosulus strain 1, pH 5.0-7.0 for L. squarrosulus strain 2, $\mathrm{pH} 5.0-5.5$ for L. strigosus strain 1, $\mathrm{pH}$ 6.0-7.5

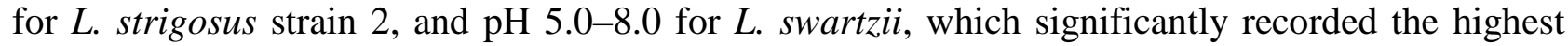
growth rates. All strains produced thick mycelia in all tested $\mathrm{pH}$ levels.

\section{Influence of aeration}

The effects of sealed (with parafilm) and unsealed conditions on the mycelial growth of seven Lentinus strains were also evaluated in this study. The growth rates of Lentinus strains incubated in two aeration conditions are shown in Table 1. It can be seen that the differences in the mycelial growth rates between two aeration conditions were not statistically significant in all Lentinus strains except L. squarrosulus strain 1.

Table 1 Effect of culture media, $\mathrm{pH}$, aeration, illumination and temperature on the mycelial growth of the seven Lentinus strains

\begin{tabular}{llllllll}
\hline Factors & \multicolumn{7}{c}{ Mycelial growth rate (day $\left.{ }^{-1}\right)$} \\
\hline $\begin{array}{l}\text { Culture } \\
\text { media }\end{array}$ & L. $s c$ & L. $s c$ & $L . s q$ & $L . s q$ & $L . s t$ & $L . s t$ & $L . s w$ \\
strain1 & strain 2 & strain1 & strain2 & strain 1 & strain 2 & \\
\hline CWG & $12.75 \pm$ & $18.00 \pm$ & $12.86 \pm$ & $12.84 \pm$ & $15.00 \pm$ & $13.87 \pm$ & $18.00 \pm$ \\
& $0.18^{\mathrm{a}}$ & $0.00^{\mathrm{a}}$ & $0.00^{\mathrm{a}}$ & $0.02^{\mathrm{a}}$ & $0.00^{\mathrm{a}}$ & $1.97^{\mathrm{a}}$ & $0.00^{\mathrm{a}}$ \\
PSG & $8.37 \pm$ & $17.22 \pm$ & $10.37 \pm$ & $4.27 \pm$ & $15.00 \pm$ & $15.00 \pm$ & $18.00 \pm$ \\
& $0.08^{\mathrm{cd}}$ & $0.28^{\mathrm{ab}}$ & $0.10^{\mathrm{b}}$ & $0.26^{\mathrm{e}}$ & $0.00^{\mathrm{a}}$ & $0.00^{\mathrm{a}}$ & $0.00^{\mathrm{a}}$ \\
CGDG & $6.80 \pm$ & $15.85 \pm$ & $9.57 \pm$ & $8.70 \pm$ & $13.80 \pm$ & $14.81 \pm$ & $18.00 \pm$ \\
& $1.55^{\mathrm{d}}$ & $0.75^{\mathrm{bc}}$ & $0.75^{\mathrm{bc}}$ & $0.05^{\mathrm{c}}$ & $0.84^{\mathrm{ab}}$ & $0.33^{\mathrm{a}}$ & $0.00^{\mathrm{a}}$ \\
RBDG & $8.79 \pm$ & $17.22 \pm$ & $12.86 \pm$ & $8.44 \pm$ & $13.20 \pm$ & $15.00 \pm$ & $17.23 \pm$ \\
& $0.06^{\mathrm{c}}$ & $0.76^{\mathrm{ab}}$ & $0.00^{\mathrm{a}}$ & $0.81^{\mathrm{cd}}$ & $0.07^{\mathrm{b}}$ & $0.00^{\mathrm{a}}$ & $0.27^{\mathrm{b}}$ \\
PDA & $10.25 \pm$ & $17.61 \pm$ & $6.89 \pm$ & $7.30 \pm$ & $14.11 \pm$ & $14.56 \pm$ & $16.27 \pm$ \\
& $0.61^{\mathrm{c}}$ & $0.03^{\mathrm{a}}$ & $0.24^{\mathrm{d}}$ & $0.76^{\mathrm{d}}$ & $0.35^{\mathrm{ab}}$ & $0.13^{\mathrm{a}}$ & $0.41^{\mathrm{c}}$ \\
MEA & $11.46 \pm$ & $14.88 \pm$ & $6.05 \pm$ & $11.20 \pm$ & $11.87 \pm$ & $14.49 \pm$ & $18.00 \pm$ \\
& $0.56^{\mathrm{ab}}$ & $0.67^{\mathrm{c}}$ & $0.20^{\mathrm{d}}$ & $0.33^{\mathrm{b}}$ & $0.74^{\mathrm{c}}$ & $0.49^{\mathrm{a}}$ & $0.16^{\mathrm{a}}$ \\
SDA & $10.91 \pm$ & $17.99 \pm$ & $9.19 \pm$ & $10.14 \pm$ & $14.66 \pm$ & $14.93 \pm$ & $8.00 \pm$ \\
& $0.59^{\mathrm{ab}}$ & $0.42^{\mathrm{a}}$ & $0.19^{\mathrm{c}}$ & $0.25^{\mathrm{b}}$ & $0.17^{\mathrm{a}}$ & $0.88^{\mathrm{a}}$ & $0.00^{\mathrm{e}}$ \\
MA & $8.78 \pm$ & $17.83 \pm$ & $4.43 \pm$ & $5.17 \pm$ & $9.44 \pm$ & $15.00 \pm$ & $11.81 \pm$ \\
& $0.61^{\mathrm{c}}$ & $0.29^{\mathrm{a}}$ & $0.19^{\mathrm{e}}$ & $0.12^{\mathrm{e}}$ & $0.43^{\mathrm{d}}$ & $0.00^{\mathrm{a}}$ & $0.12^{\mathrm{d}}$ \\
\hline
\end{tabular}


Table 1 Continued.

\begin{tabular}{|c|c|c|c|c|c|c|c|}
\hline \multirow{2}{*}{$\begin{array}{l}\text { Factors } \\
\text { pH }\end{array}$} & \multicolumn{7}{|c|}{ Mycelial growth rate $\left(\right.$ day $\left.^{-1}\right)$} \\
\hline & & & & & & & \\
\hline 5.0 & $\begin{array}{l}18.00 \pm \\
0.00^{\mathrm{a}}\end{array}$ & $\begin{array}{l}18.00 \pm \\
0.00^{\mathrm{a}}\end{array}$ & $\begin{array}{l}12.49 \pm \\
0.63^{\mathrm{a}}\end{array}$ & $\begin{array}{l}12.86 \pm \\
0.00^{\mathrm{a}}\end{array}$ & $\begin{array}{l}15.00 \pm \\
0.00^{\mathrm{a}}\end{array}$ & $\begin{array}{l}13.87 \pm \\
0.14^{\mathrm{c}}\end{array}$ & $\begin{array}{l}17.86 \pm \\
0.24^{\mathrm{a}}\end{array}$ \\
\hline 5.5 & $\begin{array}{l}17.66 \pm \\
0.23^{\mathrm{a}}\end{array}$ & $\begin{array}{l}18.00 \pm \\
0.00^{\mathrm{a}}\end{array}$ & $\begin{array}{l}11.89 \pm \\
0.10^{\mathrm{a}}\end{array}$ & $\begin{array}{l}12.86 \pm \\
0.00^{\mathrm{a}}\end{array}$ & $\begin{array}{l}13.86 \pm \\
0.14^{\mathrm{abc}}\end{array}$ & $\begin{array}{l}14.21 \pm \\
0.36^{\text {bc }}\end{array}$ & $\begin{array}{l}17.91 \pm \\
0.16^{\mathrm{a}}\end{array}$ \\
\hline 6.0 & $\begin{array}{l}16.65 \pm \\
0.09^{\mathrm{b}}\end{array}$ & $\begin{array}{l}17.53 \pm \\
0.43^{\mathrm{a}}\end{array}$ & $\begin{array}{l}11.37 \pm \\
0.15^{\mathrm{a}}\end{array}$ & $\begin{array}{l}12.86 \pm \\
0.00^{\mathrm{a}}\end{array}$ & $\begin{array}{l}13.17 \pm \\
0.21^{\text {bcd }}\end{array}$ & $\begin{array}{l}14.63 \pm \\
0.39^{\mathrm{ab}}\end{array}$ & $\begin{array}{l}18.00 \pm \\
0.00^{\mathrm{a}}\end{array}$ \\
\hline 6.5 & $\begin{array}{l}16.02 \pm \\
0.07^{\mathrm{c}}\end{array}$ & $\begin{array}{l}17.24 \pm \\
0.43^{\mathrm{a}}\end{array}$ & $\begin{array}{l}7.99 \pm \\
0.62^{\mathrm{b}}\end{array}$ & $\begin{array}{l}12.86 \pm \\
0.00^{\mathrm{a}}\end{array}$ & $\begin{array}{l}12.87 \pm \\
0.04^{\text {cd }}\end{array}$ & $\begin{array}{l}15.00 \pm \\
0.00^{\mathrm{a}}\end{array}$ & $\begin{array}{l}18.00 \pm \\
0.00^{\mathrm{a}}\end{array}$ \\
\hline 7.0 & $\begin{array}{l}14.82 \pm \\
0.29^{\mathrm{d}}\end{array}$ & $\begin{array}{l}16.13 \pm \\
0.43^{b}\end{array}$ & $\begin{array}{l}8.20 \pm \\
0.66^{\mathrm{b}}\end{array}$ & $\begin{array}{l}12.86 \pm \\
0.00^{\mathrm{a}}\end{array}$ & $\begin{array}{l}14.19 \pm \\
0.23^{\mathrm{ab}}\end{array}$ & $\begin{array}{l}15.00 \pm \\
0.00^{\mathrm{a}}\end{array}$ & $\begin{array}{l}18.00 \pm \\
0.00^{\mathrm{a}}\end{array}$ \\
\hline 7.5 & $\begin{array}{l}14.11 \pm \\
0.13^{\mathrm{e}}\end{array}$ & $\begin{array}{l}15.26 \pm \\
0.65^{\mathrm{b}}\end{array}$ & $\begin{array}{l}8.44 \pm \\
0.22^{\mathrm{b}}\end{array}$ & $\begin{array}{l}11.89 \pm \\
0.28^{\mathrm{b}}\end{array}$ & $\begin{array}{l}12.53 \pm \\
0.06^{\mathrm{d}}\end{array}$ & $\begin{array}{l}15.00 \pm \\
0.00^{\mathrm{a}}\end{array}$ & $\begin{array}{l}18.00 \pm \\
0.00^{\mathrm{a}}\end{array}$ \\
\hline 8.0 & $\begin{array}{l}13.50 \pm \\
0.18^{\mathrm{f}}\end{array}$ & $\begin{array}{l}15.14 \pm \\
0.09^{\mathrm{b}}\end{array}$ & $\begin{array}{l}7.84 \pm \\
0.21^{\mathrm{b}} \\
\end{array}$ & $\begin{array}{l}12.19 \pm \\
0.04^{\mathrm{b}}\end{array}$ & $\begin{array}{l}12.51 \pm \\
1.18^{\mathrm{d}}\end{array}$ & $\begin{array}{l}13.59 \pm \\
0.28^{\mathrm{c}}\end{array}$ & $\begin{array}{l}18.00 \pm \\
0.00^{\mathrm{a}}\end{array}$ \\
\hline \multicolumn{8}{|l|}{ Aeration } \\
\hline Sealed & $\begin{array}{l}18.00 \pm \\
0.00^{\mathrm{a}}\end{array}$ & $\begin{array}{l}18.00 \pm \\
0.00^{\mathrm{a}}\end{array}$ & $\begin{array}{l}15.00 \pm \\
0.00^{\mathrm{a}}\end{array}$ & $\begin{array}{l}12.86 \pm \\
0.00^{\mathrm{a}}\end{array}$ & $\begin{array}{l}14.59 \pm \\
0.37^{\mathrm{a}}\end{array}$ & $\begin{array}{l}15.00 \pm \\
0.00^{\mathrm{a}}\end{array}$ & $\begin{array}{l}18.00 \pm \\
0.00^{\mathrm{a}}\end{array}$ \\
\hline Unsealed & $\begin{array}{l}18.00 \pm \\
0.00^{\mathrm{a}}\end{array}$ & $\begin{array}{l}18.00 \pm \\
0.00^{\mathrm{a}}\end{array}$ & $\begin{array}{l}13.78 \pm \\
0.13^{\mathrm{b}}\end{array}$ & $\begin{array}{l}12.86 \pm \\
0.16^{\mathrm{a}}\end{array}$ & $\begin{array}{l}15.00 \pm \\
0.00^{\mathrm{a}}\end{array}$ & $\begin{array}{l}15.00 \pm \\
0.00^{\mathrm{a}}\end{array}$ & $\begin{array}{l}18.00 \pm \\
0.00^{\mathrm{a}}\end{array}$ \\
\hline \multicolumn{8}{|c|}{ Illumination } \\
\hline Lighted & $\begin{array}{l}18.00 \pm \\
0.00^{\mathrm{a}}\end{array}$ & $\begin{array}{l}18.00 \pm \\
0.00^{\mathrm{a}}\end{array}$ & $\begin{array}{l}15.00 \pm \\
0.84^{\mathrm{a}}\end{array}$ & $\begin{array}{l}15.00 \pm \\
0.00^{\mathrm{a}}\end{array}$ & $\begin{array}{l}15.00 \pm \\
0.00^{\mathrm{a}}\end{array}$ & $\begin{array}{l}15.00 \pm \\
0.00^{\mathrm{a}}\end{array}$ & $\begin{array}{l}18.00 \pm \\
0.00^{\mathrm{a}}\end{array}$ \\
\hline Dark & $\begin{array}{l}18.00 \pm \\
0.00^{\mathrm{a}}\end{array}$ & $\begin{array}{l}18.00 \pm \\
0.00^{\mathrm{a}}\end{array}$ & $\begin{array}{l}13.10 \pm \\
0.00^{\mathrm{b}}\end{array}$ & $\begin{array}{l}14.58 \pm \\
0.00^{\mathrm{b}}\end{array}$ & $\begin{array}{l}13.10 \pm \\
0.99^{\mathrm{b}}\end{array}$ & $\begin{array}{l}15.00 \pm \\
0.00^{\mathrm{a}}\end{array}$ & $\begin{array}{l}18.00 \pm \\
0.00^{\mathrm{a}}\end{array}$ \\
\hline \multicolumn{8}{|c|}{ Temperature } \\
\hline $9^{\circ} \mathrm{C}$ & ng & ng & ng & ng & ng & ng & ng \\
\hline $23^{\circ} \mathrm{C}$ & $\begin{array}{l}18.00 \pm \\
0.00^{\mathrm{a}}\end{array}$ & $\begin{array}{l}20.31 \pm \\
0.24^{\mathrm{b}}\end{array}$ & $\begin{array}{l}15.00 \pm \\
0.00^{\mathrm{a}}\end{array}$ & $\begin{array}{l}14.58 \pm \\
0.14^{\mathrm{b}}\end{array}$ & $\begin{array}{l}13.19 \pm \\
0.11^{\mathrm{b}}\end{array}$ & $\begin{array}{l}13.98 \pm \\
0.19^{\mathrm{b}}\end{array}$ & $\begin{array}{l}16.86 \pm \\
0.24^{\mathrm{b}}\end{array}$ \\
\hline $30^{\circ} \mathrm{C}$ & $\begin{array}{l}18.00 \pm \\
0.00^{\mathrm{a}}\end{array}$ & $\begin{array}{l}22.50 \pm \\
0.00^{\mathrm{a}}\end{array}$ & $\begin{array}{l}15.00 \pm \\
0.00^{\mathrm{a}}\end{array}$ & $\begin{array}{l}15.00 \pm \\
0.00^{\mathrm{a}}\end{array}$ & $\begin{array}{l}15.00 \pm \\
0.00^{\mathrm{a}}\end{array}$ & $\begin{array}{l}15.00 \pm \\
0.00^{\mathrm{a}}\end{array}$ & $\begin{array}{l}18.00 \pm \\
0.00^{\mathrm{a}}\end{array}$ \\
\hline
\end{tabular}

Means with similar superscripts are statistically comparable from each other using Tukeys HSD and t-test at $5 \%$ level of significance. L. sc, Lentinus sajor-caju; L. sq, Lentinus squarrosulus; L. st, Lentinus strigosus; L. sw, Lentinus swartzii; CWG, coconut water gulaman; PSG, potato sucrose gulaman; CGDG, corn grit decoction gulaman; RBDG, rice bran decoction gulaman; PDA, potato dextrose agar; MEA, malt extract agar; SDA, Sabouraud dextrose agar; MA, mycological agar; ng, no growth.

\section{Influence of illumination}

The influence of the presence and absence of light on the mycelial growth of Lentinus strains was investigated. Culture plates were incubated under artificial light and in dark conditions. The mycelial growth rates of seven Lentinus mushrooms as affected by the two illumination conditions are presented in Table 1. Both conditions were found suitable for the luxuriant growth of mycelia of two strains of L. sajor-caju, L. strigosus strain 2 and L. swartzii. However, mycelia of two strains of L. squarrosulus and L. strigosus strain 1 grown in the lighted condition significantly recorded higher growth rates than those incubated in the dark.

\section{Influence of temperature}

The influence of temperature on the mycelia growth of seven Lentinus strains was studied. Table 1 shows the growth rates of Lentinus mushrooms as affected by the three temperature conditions. All Lentinus strains evaluated recorded the highest mycelial growth rates and very thick mycelia at $30^{\circ} \mathrm{C}$. However, mycelial growth rates of L. sajor-caju strain 1 and L. squarrosulus 
strain 1 incubated at $30^{\circ} \mathrm{C}$ were not significantly different from those incubated at $23^{\circ} \mathrm{C}$. No mycelial growth was observed at $9^{\circ} \mathrm{C}$.

\section{Fructification on rice straw and sawdust-based substrate}

After determining the nutritional and physical requirements for mycelial growth of the seven Lentinus strains, their fructification abilities by using lignocellulosic agro-industrial as substrates in fruiting bags in growing house conditions were also investigated. The Center for Tropical Mushroom Research and Development (CTMRD) formulation consisting of 7:3 v/v ratio of rice straw and sawdust was used in this study. The fructification parameters of the seven Lentinus strains are shown in Table 2. Inoculated fruiting bags were incubated in the required environmental conditions and the incubation days for mycelial colonization was recorded. Both strains of $L$. strigosus and sole strain of $L$. swartzii displayed the shortest incubation periods of 18-18.8 days followed by both strains of $L$. sajor-caju with 20.9-21.3 days. On the other hand, both strains of $L$. squarrosulus registered the most extensive incubation period of 25.5-25.6 days. Comparing the two strains of each Lentinus species, t-test revealed no significant difference.

Once fully ramified with mycelia, the next cultivation phase observed was the initiation of primordia or also known as fruiting initials. Similarly, both strains of L. strigosus and sole strain of L. swartzii showed the earliest primordia after 21.6-22.3 days, whereas both strains of $L$. squarrosulus showed the latest primordia after 31.9-33.5 days. Again, no significant difference was found between two strains of each species according to t-test.

The fruiting bags were opened and watered allowing the primordia to develop into mature fruiting bodies. The fruiting bodies of different Lentinus strains grown on rice straw and sawdustbased substrate formulation are shown in Fig. 1. In terms of cap diameter, t-test revealed a significant difference between strains of L. strigosus. Strain 2 had a wider cap diameter (51.97 mm) than strain $1(28.52 \mathrm{~mm})$. However, no significant difference regarding the cap diameter was found between strains of L. sajor-caju and strains of L. squarrosulus. Among species, L. sajor-caju showed the widest cap diameter. Looking at the stipe length, significant difference was only found between strains of L. squarrosulus, while no significant difference was noted between strains of both $L$. sajor-caju and L. strigosus. The longest stipe was recorded in L. squarrosulus strain 1 with a mean of $53.54 \mathrm{~mm}$ while the shortest stipe was registered in L. squarrosulus strain 2 with a mean of $8.09 \mathrm{~mm}$.

Table 2 Fructification parameters of the seven strains of Lentinus

\begin{tabular}{|c|c|c|c|c|c|c|}
\hline Lentinus & $\begin{array}{l}\text { Incubation } \\
\text { period } \\
\text { (day) }\end{array}$ & $\begin{array}{l}\text { Primordia } \\
\text { initiation } \\
\text { (day) }\end{array}$ & $\begin{array}{l}\text { Cap } \\
\text { diameter } \\
(\mathbf{m m})\end{array}$ & $\begin{array}{l}\text { Stipe } \\
\text { length } \\
(\mathbf{m m})\end{array}$ & $\begin{array}{l}\text { Yield } \\
\left(\mathrm{g} \mathrm{bag}^{-1}\right)\end{array}$ & $\begin{array}{l}\text { Biological } \\
\text { efficiency } \\
(\%)\end{array}$ \\
\hline L. $s c$ strain 1 & $20.9 \pm 0.7$ & $24.0 \pm 0.8$ & $60.7 \pm 6.6$ & $14.5 \pm 1.3$ & $44.2 \pm 6.7$ & $8.8 \pm 1.3$ \\
\hline L. $s c$ strain 2 & $21.3 \pm 1.1$ & $24.5 \pm 1.1$ & $62.7 \pm 4.4$ & $14.8 \pm 1.6$ & $50.9 \pm 6.3$ & $10.2 \pm 1.3$ \\
\hline L. $s q$ strain 1 & $25.6 \pm 2.3$ & $31.9 \pm 2.8$ & $45.8 \pm 7.6$ & $53.5 \pm 8.3^{*}$ & $36.4 \pm 10.9^{*}$ & $7.3 \pm 2.2^{*}$ \\
\hline L. $s q$ strain 2 & $25.5 \pm 2.6$ & $33.5 \pm 2.9$ & $45.5 \pm 6.8$ & $8.1 \pm 1.9$ & $23.5 \pm 8.6$ & $4.7 \pm 1.7$ \\
\hline L. st strain 1 & $18.0 \pm 0.8$ & $21.6 \pm 0.5$ & $28.5 \pm 5.1$ & $19.6 \pm 1.9$ & $52.5 \pm 12.7^{*}$ & $10.5 \pm 2.6^{*}$ \\
\hline L. st strain 2 & $18.8 \pm 2.8$ & $22.3 \pm 2.9$ & $51.9 \pm 9.3^{*}$ & $19.7 \pm 2.6$ & $21.1 \pm 7.4$ & $4.2 \pm 1.5$ \\
\hline L. $s w$ & $18.4 \pm 1.4$ & $22.0 \pm 1.6$ & $40.6 \pm 1.71$ & $36.5 \pm 3.3$ & $34.6 \pm 5.9$ & $6.9 \pm 1.2$ \\
\hline
\end{tabular}

Asterisk (*) indicates significant difference between two strains of each Lentinus species (except L. swartzii) using t-test at 5\% level of significance. L. sc, Lentinus sajor-caju; L. sq, Lentinus squarrosulus; L. st, Lentinus strigosus; L. sw, Lentinus swartzii.

The yield and biological efficiency of seven Lentinus strains are presented in Table 2. Significant difference between strains of the same species was observed in $L$. squarrosulus and $L$. strigosus. In both species, strain 1 produced higher yields of $36.4 \mathrm{~g} \mathrm{bag}^{-1}$ and $52.5 \mathrm{~g} \mathrm{bag}^{-1}$ with corresponding biological efficiency of $7.27 \%$ and $10.50 \%$, respectively. On the other hand, strain 2 of both Lentinus species produced the lowest yields of $23.5 \mathrm{~g} \mathrm{bag}^{-1}$ (4.7\% bio-efficiency) and 21.1 


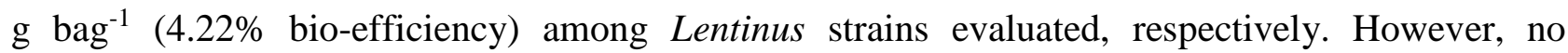
significant difference was found between strains of $L$. sajor-caju. Strain 1 displayed a yield of 44.2 $\mathrm{g} \mathrm{bag}^{-1}$ (8.84\% bio-efficiency) whereas strain 2 showed a yield of $50.9 \mathrm{~g} \mathrm{bag}^{-1}$ (10.18\% bioefficiency). The sole strain of L. swartzii, however, recorded a yield of $34.6 \mathrm{~g} \mathrm{bag}^{-1}$ with $6.92 \%$ biological efficiency.

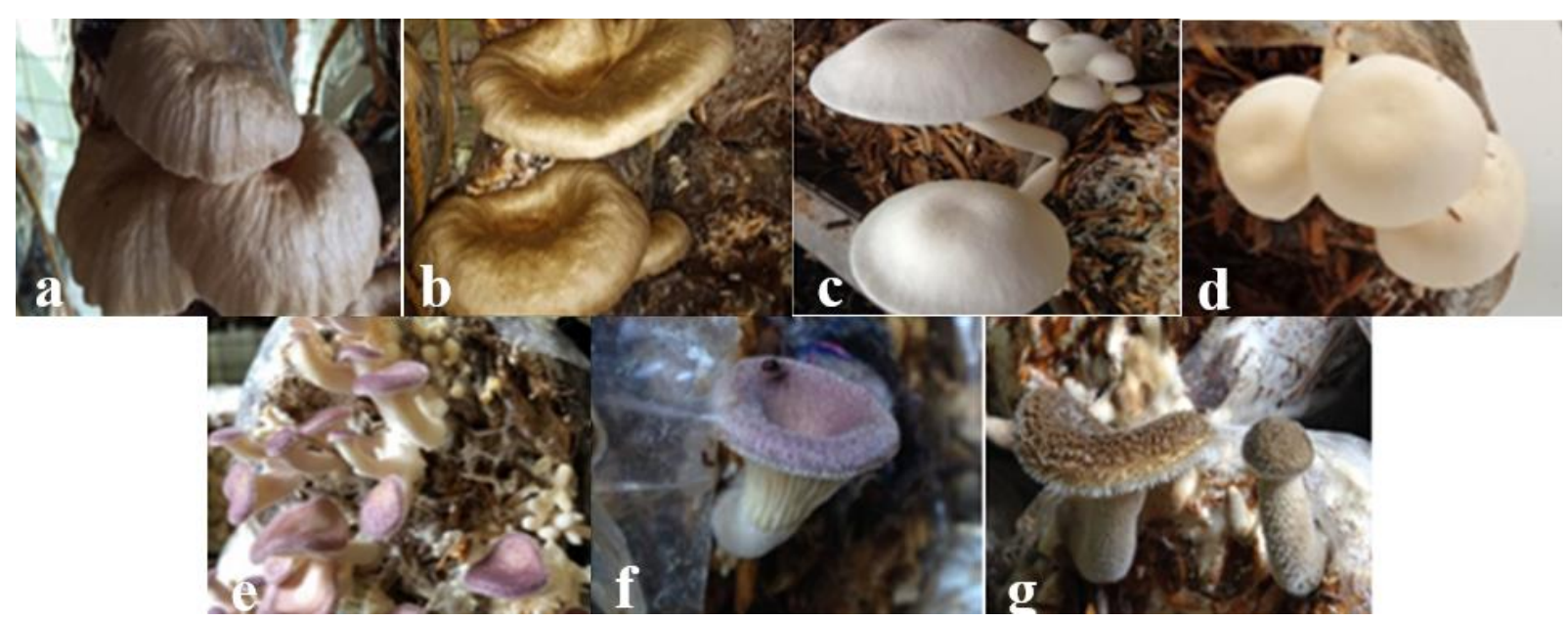

Fig. 1 - Fruit bodies of Lentinusspecies/strains growing on fruiting bags containing 7:3 rice strawsawdust substrate formulation. a $L$. sajor-caju strain $1 . \quad b \quad L$. sajor-caju strain 2. c L. squarrosulus strain 1. d L. squarrosulus strain 2. e L. strigosus strain 1. f L. strigosus strain 2. g L. swartzii.

\section{Discussion}

The suitable culture medium and its natural nutritional components are the most critical requirement for the growth of mushroom mycelia. CWG was found to be the most suitable medium for the efficient mycelial growth of the seven strains of Lentinus. However, other culture media were also suitable for the mycelial growth of Lentinus species. These suggest that the mycelial growth performance of Lentinus on the different culture media may vary depending on the species and strain. This could be due to the unique inherent characteristics of individual mushroom formed in heterogeneous natural habitat. Accordingly, species and even strain could be categorized as slow-growing and fast-growing mushrooms.

Similarly, CWG was the preferred medium for the efficient mycelial growth of Central Luzon strain of L. tigrinus, Botolan strain of $L$. squarrosulus, Ifugao strain of $L$. sajor-caju, BIL1324 strain of L. strigosus, and Central Luzon strain of L. swartzii (De Leon et al. 2013, 2017a, Dulay et al. 2012, 2017b, 2021a). The results of the present study and these previous findings clearly suggest that CWG is the best medium for the maximum growth of Lentinus mycelia. Moreover, CWG is also the best medium for the luxuriant mycelial growth of other mushroom species including Ganoderma lucidum and Auricularia polytricha in semi-solid state, and Schizophyllum commune and Volvariellavolavacea in liquid state (Magday et al. 2014, Kalaw et al. 2016, Dulay et al. 2016). The better performance of mushroom mycelia on CWG could be accounted to the natural nutrient components of coconut water, which are very essential for the growth of fungal cells. Coconut water contains carbohydrates, sugars, dietary fiber, protein, fat, vitamins and minerals (USDA 2019). Although these nutrients are also available in other culture media evaluated, the types (e.g. sugar constituents) and their corresponding amount vary from one medium to another, which greatly influence on the growth of mycelia. Dulay et al. (2020b) evaluated the nutritional requirements of the three Lentinus species and found that the mycelia of L. swartzii, L. strigosus, and L. tigrinus favorably grew on starch, fructose, and sucrose as carbon sources and ammonium chloride, yeast extract, and malt extract as nitrogen sources at $\mathrm{C} / \mathrm{N}$ ratio of 10:1, 10:1, and 40:1, respectively. 
In addition, Itoo \& Reshi (2014) reported that Cortinariusflexipes and Cortinariusfulvoconicus exhibited maximum mycelial growth at $>20 \mathrm{~g} / \mathrm{L}$ glucose, while Tricholoma aurantium, Suillus luteus, Laccarialaccata and Scleroderma citrinum showed maximum growth at $20 \mathrm{~g} / \mathrm{L}$ glucose. Di-ammonium hydrogen orthophosphate at 5-10 g/L was the optimum nitrogen source of the six ectomycorrhizal species. Apart from carbon and nitrogen sources, minerals such as $\mathrm{KH}_{2} \mathrm{PO}_{4}$ for L. swartzii, $\mathrm{ZnSO}_{4} \bullet 7 \mathrm{H}_{2} \mathrm{O}$ for L. strigosus, and all minerals tested except $\mathrm{CuSO}_{4} \cdot 5 \mathrm{H}_{2} \mathrm{O}$ for L. tigrinus and organic acids such as lactic acid, acetic acid and citric acid also enhanced the mycelial growth (Dulay et al. 2020b). Accordingly, mushrooms have specific nutrient type and quantity requirements, which are naturally present in their most suitable culture medium. Therefore, it is of high interest to also determine the specific nutrient sources of the seven Lentinus strains evaluated in the present study.

The optimal $\mathrm{pH}$ of the most suitable medium for each Lentinus strain was also determined. It was established that Lentinus mycelia requires a slightly acidic to neutral $\mathrm{pH}$ of the culture medium to produce superior mycelial growth. This finding of the present study conforms to our previous reports that the optimum $\mathrm{pH}$ for the luxuriant growth of L. strigosus BIL1324 strain, L. swartzii Central Luzon strain, and Ganoderma lucidum is pH 6 (Dulay \& Garcia 2017, Dulay et al. 2021a, Magday et al. 2014). However, Botolan strain of L. squarrosulus and Central Luzon strain of $L$. tigrinus grew best at $\mathrm{pH}$ 6.5-7 and 7-8, respectively (Dulay et al. 2012, De Leon et al. 2017b), whereas Ifugao strain of L. sajor-caju exceedingly favoured $\mathrm{pH} 5$ (De Leon et al. 2017a). Therefore, it is safe to mention that a $\mathrm{pH}$ range of 5-8 is the optimal $\mathrm{pH}$ for the growth of different species and even strains of Lentinus mycelia.

Aeration refers to the air composition or level of oxygen and carbon dioxide in the culture. The results of the present study showed that aeration is not a major physical factor that affects the growth of mycelia of the six strains, in which they could grow in either aerobic or anaerobic state. This response to aeration conditions is also observed in L. sajor-caju Ifugao strain and L. tigrinus Central Luzon strain (Dulay et al. 2012, De Leon et al. 2017a). However, L. squarrosulus strain 1 significantly favored sealed condition indicating that this strain does not require direct exposure to air. The same condition is the requirement of L. strigosus BIL 1324 strain and L. squarrosulus Botolan strain and L. swartzii Central Luzon strain (Dulay et al. 2021a, Dulay \& Garcia 2017, De Leon et al. 2017b). In submerged cultivation of mycelia, agitation is applied to introduce aeration in the culture effectively. Agitation at $100 \mathrm{rpm}$ improves the biomass yield of G. lucidum in shakeflask culture, whereas static culture condition is found suitable for the mycelial production of Schizophyllum commune, Pleurotuscystidiosus, and Volvariellavolvacea (Dulay et al. 2015).

Light regulates the growth, and reproduction of fungi which is necessary for their distribution and survival (Idnurm \& Heitman 2005). Illumination is another important environmental factor that influences the growth of mushrooms. It was found that each Lentinus strain has a unique illumination preference. Previously, the lighted condition was found to stimulate the growth of mycelia of $L$. sajor-caju Ifugao strain (De Leon et al. 2017a). Contrastingly, the dark condition is more suitable for L. tigrinus Central Luzon strain, L. strigosus BIL 1324 strain and L. swartzii Central Luzon strain (Dulay et al. 2012, 2021a, Dulay \& Garcia 2017). Since some mushrooms positively respond to lighted condition, it is also necessary to evaluate the effects of different light wavelengths and intensities on the mycelial growth. In our previous work, we found that blue LED enhances the mycelial growth, fruiting body yield and bio-efficiency of L. tigrinus (Damaso et al. 2018). However, in liquid culture, red LED stimulates mycelial growth and improves the fruiting body yield of $L$. swartzii (Tiniola et al. 2021). In addition, the positive effects of blue light on the metabolism, growth and development, fruiting body induction, and primordium differentiation into fruiting body in mushrooms have been widely reported (Kojima et al. 2015, Sakamoto et al. 2018, Sakamoto 2018).

Lentinus grows in a wide range of temperatures, from tropical to temperate regions of the Earth. Hence, temperature is very vital in the survival and distribution of mushrooms. The results suggest that the seven Lentinus strains are classified as tropical mushrooms. The $30^{\circ} \mathrm{C}$ is also the reported temperature requirement for the mycelial growth of other Lentinus species/strains 
including L. sajor-caju Ifugao strain, L. swartzii Central Luzon strain (De Leon et al. 2017a, Dulay et al. 2021a) and other Philippine basidiomycetes such as G. lucidum, V. volvacea and Trametes elegans (Dulay et al. 2015, 2021b). However, L. tigrinus Central Luzon strain, L. squarrosulus Botolan strain, L. strigosus BIL1324 strain preferred $32^{\circ} \mathrm{C}$ (Dulay et al. 2012, Dulay \& Garcia 2017, De Leon et al. 2017b). Contrastingly, their relative L. edodes is a semi-temperate species, which demonstrates optimal mycelial growth at $25^{\circ} \mathrm{C}$ (Chen 2004).

Fructification is an indicative of the cultivation potential of wild mushrooms prior to the generation of production technology necessary for mass production and even commercialization. The present study suggests that the different strains and species of Lentinus respond differently in terms of fruiting body production when cultivated on rice straw and sawdust-based substrate formulation. Variation in fruiting body production performance is also observed among five strains of L. edodes (Gaitan-Hernandez \& Mata 2004) and three strains of Pleurotus eryngii (Moonmoon et al. 2010). This variation could be attributed to the genotype and physiological differences among mushroom strains. The yields and biological efficiencies of the seven Lentinus strains presented in this study are comparatively lower than the reported biological efficiencies of wild mushrooms such as L. tigrinus Central Luzon strain (15.93\%) and L. strigosus BIL1324 strain (20.97\%) (Dulay et al. 2012, 2017b), and commercially-cultivated L. edodes (46-80\%) (Royse 1995). In our previous work, with the intention to improve the biological efficiency of L. strigosus BIL1324 strain, we reported that the addition of $20 \%$ rice bran and $20 \%$ corn grit to rice straw stimulates the formation of primordia, produces higher yield and improves the biological efficiency by $41.96 \%$ in rice bran and $40.86 \%$ in corn grit (Dulay \& Garcia 2017).

This work has established the suitable culture media, optimal $\mathrm{pH}$, and physical environmental requirements such as aeration, illumination and temperature for the luxuriant growth of mycelia of seven wild Lentinus strains. Moreover, the fructification abilities of seven Lentinus strains were also established, suggesting their promising cultivation potential using rice straw and sawdustbased substrate formulation in growing house conditions. Variation between strains is evident in the mycelial growth and fruiting body performance of each species, indicating that strain selection is also very important in mushroom production. However, further investigation on the effect of supplemented substrates in fruiting body cultivation must be done in order to improve the yield and biological efficiency.

\section{Acknowledgements}

This work was funded by the Philippine Council for Health Research and Development, Department of Science and Technology.

\section{References}

Arenas MC, Tadiosa ER, Reyes RG. 2015 - Macroscopic Fungi of Mts. Banahaw-San Cristobal Protected Landscape Northwestern side, with a description of Nidula banahawensis sp. nov. (Basidiomycota). Asian Journal of Biodiversity 6(2), 69-88.

Arenas MC, Tadiosa ER, Reyes RG. 2018 - Taxonomic inventory based on physical distribution of macrofungi in Mt. Maculot, Cuenca, Batangas, Philippines. International Journal of Biology, Pharmacy and Allied Sciences 7(5), 672-687.

Austria AB, Dulay RMR, Pambid RC. 2021 - Mycochemicals, antioxidant and anti-diabetic properties of Philippine sawgill mushroom Lentinus swartzii (higher basidiomycetes). Asian Journal of Agriculture and Biology 2021(2), 202006365.

Bengu AS. 2020 - The fatty acid composition in some economic and wild edible mushrooms in Turkey. Progress in Nutrition 22(1), 185-192.

Chen A. 2004 - Growing shiitake mushroom. In Mushroom grower's handbook 1: Oyster mushroom cultivation. Seoul, Korea: MushWorld-Heineart Inc. p. 248-261. 
Chung I-M, Kim J-K, Han J-G, Kong W-S et al. 2019 - Potential geo-discriminative tools to trace the origins of the dried slices of shiitake (Lentinula edodes) using stable isotope ratios and OPLS-DA. Food Chemistry 295, 505-513.

Culala JM, Dulay RMR. 2018 - Species listing of naturally occurring mushrooms in Central Luzon State University, Science City of Munoz, Nueva Ecija, Philippines. International Journal of Biology, Pharmacy and Allied Sciences 7(10), 1890-1899.

Damaso Jr. EJ, Dulay RMR, Kalaw SP, Reyes RG. 2018 - Effects of color light emitting diode (LED) on the mycelial growth, fruiting body production, and antioxidant activity of Lentinus tigrinus. CLSU International Journal of Science and Technology 3(2), 9-16.

De Castro MEG, Dulay RMR. 2015 - Macrofungi in multistorey agroforestry systems in Mt. Makiling Forest Reserve, Los Banos, Laguna, Philippines. Journal of Chemistry, Biology \& Physical Sciences 5(2), 1646-1655.

De Leon AM, Guinto LJZG, De Ramos PDV, Kalaw SP. 2017b - Enriched cultivation of Lentinus squarrosulus (Mont.) Singer: A newly domesticated wild edible mushroom in the Philippines. Mycosphere 8(3), 615-629.

De Leon AM, Orpilla JOV, Cruz KV, Dulay RMR et al. 2017a - Optimization of mycelial growth and mycochemical screening of Lentinus sajor-caju (Fr.) from Banaue, Ifugao Province, Philippines. International Journal of Agricultural Technology 13(7.3), 2549-2567.

De Leon AM, Reyes RG, Dela Cruz TE. 2013 - Lentinus squarrosulus and Polyporus grammocephalus: newly domesticated, wild edible macrofungi from the Philippines. Philippine Agricultural Scientist 96, 411-418.

De Leon AM, Reyes RG, dela Cruz TEE. 2012 - An ethnomycological survey of macrofungi utilized by Aeta communities in Central Luzon, Philippines. Mycosphere 3(2), 251-259.

Dulay RM, Arenas MC, Kalaw SP, Reyes RG, Cabrera EC. 2014 - Proximate composition and functionality of the culinary-medicinal tiger sawgill mushroom, Lentinus tigrinus (higher Basidiomycetes), from the Philippines. International Journal of Medicinal Mushrooms 16(1), 85-94.

Dulay RM, Carandang JS, Kalaw S, Reyes R. 2020a - Distribution and species listing of wild macrofungi in sitio Canding, Barangay Maasin, San Clemente, Tarlac Province, Philippines. Journal of Applied Biology and Biotechnology 8(05), 7-15.

Dulay RM, Miranda LA, Malasaga JS, Kalaw SP et al. 2017a - Antioxidant and antibacterial activities of acetonitrile and hexane extracts of Lentinus tigrinus and Pleurotus djamour. Biocatalysis and Agricultural Biotechnology 9, 141-144.

Dulay RM, Rivera AG, Garcia EJB. 2017b - Mycelial growth and basidiocarp production of wild hairy sawgill Lentinus strigosus, a new record of naturally occurring mushroom in the Philippines. Biocatalysis and Agricultural Biotechnology 10, 242-246.

Dulay RMR, Alcazar AA, Kalaw SP, Reyes RG, Cabrera EC. 2021b - Nutritional and physical requirements for mycelial growth and basidiocarp production of Trametes elegans from the Philippines. Asian Journal of Agriculture and Biology 2021(1), 202006339.

Dulay RMR, Cabrera EC, Kalaw SP, Reyes RG, Hou CT. 2020b - Nutritional requirements for mycelial growth of three Lentinus species from the Philippines. Biocatalysis and Agricultural Biotechnology 23, 101506.

Dulay RMR, Cabrera EC, Kalaw SP, Reyes RG. 2021a - Optimization of culture conditions for mycelial growth and fruiting body production of naturally-occurring Philippine mushroom Lentinus swartzii Berk. Journal of Applied Biology and Biotechnology 9(3), 17-25.

Dulay RMR, Garcia EJB. 2017 - Optimization and enriched cultivation of Philippine (CLSU) strain of Lentinus strigosus (BIL1324). Biocatalysis and Agricultural Biotechnology 12, 323328.

Dulay RMR, Kalaw SP, Reyes RG, Cabrera EC, Alfonso NF. 2012 - Optimization of culture conditions for mycelial growth and basidiocarp production of Lentinus tigrinus (Bull.) Fr., a new record of domesticated wild edible mushroom in the Philippines. Philippine Agricultural Scientist 95(3), 278-285. 
Dulay RMR, Maglasang CC. 2017 - Species listing of naturally occurring mushrooms in agroecosystem of Barangay Bambanaba, Cuyapo, Nueva Ecija, Philippines. International Journal of Biology, Pharmacy and Allied Sciences 6(8), 1459-1472.

Dulay RMR, Pamiloza DG. 2018 - Proximate composition and bioactivities of hairy sawgill mushroom, Lentinus strigosus (BIL 1324) from the Philippines. International Journal of Biology, Pharmacy and Allied Sciences 7(3), 361-369.

Dulay RMR, Ray K, Hou CT. 2015 - Optimization of liquid culture conditions of Philippine wild edible mushrooms as potential source of bioactive lipids. Biocatalysis and Agricultural Biotechnology 4, 409-415.

Dulay RMR, Vicente JJA, Dela Cruz AG, Gagarin JM et al. 2016 - Antioxidant activity and total phenolic content of Volvariella volvacea and Schizophyllum commune mycelia cultured in indigenous liquid media. Mycosphere 7(2), 131-138.

Gaitan-Hernandez R, Mata G. 2004 - Cultivation of edible mushrooms Lentinula edodes (shiitake) in pasteurized wheat straw - alternative use of geothermal energy in Mexico. Engineering in Life Science 4(4), 363-367.

Idnurm A, Heitman J. 2005 - Light controls growth and development via a conserved pathway in the fungal kingdom. PLoS Biology 3(4), 615-626.

Itoo ZA, Reshi ZA. 2014 - Effect of different nitrogen and carbon sources and concentrations on the mycelial growth of ectomycorrhizal fungi under in-vitro conditions. Scandinavian Journal of Forest Research 29(7), 619-628.

Kalaw SP, Alfonso DO, Dulay RMR, De Leon AM et al. 2016 - Optimization of culture conditions for secondary mycelial growth of wild edible mushrooms from selected areas in Central Luzon, Philippines. Current Research in Environment and Applied Mycology 6(4), 277-287.

Kojima M, Kimura N, Miura R. 2015 - Regulation of primary metabolic pathways in oyster mushroom mycelia induced by blue light stimulation: accumulation of shikimic acid. Scientific Reports 5(1), 8630.

Kupcova K, Stefanova I, Plavcova Z, Hosek J et al. 2018 - Antimicrobial, cytotoxic, antiinflammatory, and antioxidant activity of culinary processed shiitake medicinal mushroom (Lentinus edodes, Agaricomycetes) and its major sulfur sensory-active compound lenthionine. International Journal of Medicinal Mushrooms 20(2), 165-175.

Magday Jr. JC, Bungihan ME, Dulay RMR. 2014 - Optimization of mycelial growth and cultivation of fruiting body of Philippine wild strain of Ganoderma lucidum. Current Research in Environment and Applied Mycology 4(2), 162-172.

Moonmoon M, Uddin MN, Ahmed S, Shelly NJ, Khan MA. 2010 - Cultivation of different strains of king oyster mushroom (Pleurotus eryngii) on sawdust and rice straw in Bangladesh. Saudi Journal of Biological Science 17, 341-345.

Painuli S, Semwal P, Egbuna C. 2020 - Mushroom: Nutraceutical, Mineral, Proximate Constituents and Bioactive Component. In: Egbuna C., Dable Tupas G. (eds) Functional Foods and Nutraceuticals. Springer, Cham.

Rathore H, Prasad S, Sharma S. 2017 - Mushroom nutraceuticals for improved nutrition and better human health: A review. PharmaNutrition 5(2), 35-46.

Royse DJ. 1995 - Effect of spawn run time and substrate nutrition on the yield and size of shiitake mushroom. Mycologia 77, 756-762.

Sakamoto Y. 2018 - Influences of environmental factors on fruiting body induction, development and maturation in mushroom-forming fungi. Fungal Biology Review 32(4), 236-48.

Sakamoto Y, Sato S, Ito M, Nakahori K, Muraguchi H. 2018 - Blue light exposure and nutrient conditions influence the expression of genes involved in simultaneous hyphal knot formation in Coprinopsis cinerea. Microbiology Research 217, 81-90.

Tadiosa ER, Arsenio JS. 2014 - A taxonomic study of wood-rotting Basidiomycetes at the molave forest of San Fernando City, La Union Province, Philippines. Asian Journal of Biodiversity 5, 92-108. 
Tiniola RC, Pambid RC, Bautista AS, Dulay RMR. 2021 - Light-emitting diode enhances the biomass yield and antioxidant activity of Philippine wild mushroom Lentinus swartzii. Asian Journal of Agriculture and Biology 2021(2), 202008435.

Udchumpisai U, Bangyeekhun E. 2019b - Evaluation of the cytotoxic effect of crude aqueous and ethanolic extracts isolated from Lentinus sp. on human cancer cell lines. Malaysian Journal of Microbiology 15, 8-15.

Udchumpisai W, Bangyeekhun E. 2019a - Purification, Structural Characterization, and Biological Activity of Polysaccharides from Lentinus velutinus. Mycobiology 48(1), 51-57.

USDA. 2019 - United States Department of Agriculture - FoodData Central. Nuts, coconut water (liquid from coconuts). Available at https://fdc.nal.usda.gov/fdc-app.html\#/fooddetails/170174/nutrients (Accessed on December 19, 2020)

Wang L, Wang C, Gao X, Xu N et al. 2015 - Purification, characterization and anti-aging capacity of mycelia zinc polysaccharide by Lentinus edodes SD-08. BMC Complementary and Alternative Medicine 15, 111.

Xu LJ, Wang HX, Ng TB. 2012 - A laccase with HIV-1 reverse transcriptase inhibitory activity from the broth of mycelial culture of the mushroom Lentinus tigrinus. Journal of Biomedicine and Biotechnology 7, 536725.

$\mathrm{Xu}$ X, Yan H, Tang J, Chen J, Zhang X. 2014 - Polysaccharides in Lentinus edodes: Isolation, structure, immunomodulating activity and future prospective. Critical Reviews in Food Science and Nutrition 54(4), 474-487. 